\title{
Inheritance Tax Laws, As Affecting Powers of Appointment
}

$\infty$ INCE the adoption of inheritance tax laws in almost every state in the Union, and by the Federal government, the subject of inheritance taxation has become one of great importance. Almost every estate over $\$ 50,000$ (the amount exempted under the Federal estate tax act) presents some question of difficulty and moment under the inheritance tax laws. The courts of the western states have, so far, passed on only a few of the principal questions, such as the constitutionality of various provisions, contemplation of death, and transfers intended to take effect in possession or enjoyment at, or after, death.

Among the questions that western courts have seldom been called to pass upon are the taxability of the exercise of powers of appointment, contained in wills and deeds, and the effect of failure to exercise such powers of appointment.

These questions give promise of becoming important in California, since many wealthy persons from the eastern states, where the use of the power of appointment is more common and better known than it is in the western states, have executed wills and deeds containing powers of appointment and have thereafter established domicile in California and died there.

The powers of appointment that will be considered here are those giving an authority to a party to dispose of real or personal property for the benefit of others and operating upon an estate or interest vested either in himself or some other person. Many interesting questions arise where the person executing an instrument creating estates in property reserves a power of appointment to himself, but limitations of space will not permit of their discussion here.

A will or deed containing such a power of appointment may have become effective prior to the passage of any inheritance tax act and the power therein contained may have been exercised 
subsequent to the passage of an inheritance tax statute taxing the exercise, or the power may never have been exercised. This may raise the question whether any tax is due. Furthermore, an instrument giving a power of appointment may have taken effect while a state or Federal inheritance tax act provided a comparatively low rate of taxation, and the power of appointment may have been exercised while a comparatively high rate of taxation was in effect. Then the question might arise as to whether the lower or higher rate of taxation should be applied.

The legislature of California in 1917, probably because of the migration to California of affluent easterners familiar with powers of appointment, amended the inheritance tax statute by adding an interesting provision with regard to powers of appointment, which appears to have been copied from one of the earlier New York statutes, ${ }^{1}$ and the second part of which was there held unconstitutional in $1905^{2}$ and repealed in $1911 .^{3}$ The provision reads as follows:

"Whenever any person, trustee or corporation shall exercise a power of appointment derived from any disposition of property made either before or after the passage of this act, such appointment, when made, shall be deemed a transfer taxable under the provisions of this act, in the same manner as though the property to which such appointment relates belonged absolutely to the donee of such power, and had been bequeathed or devised by such donee by will; and whenever any person, trustee or corporation possessing such power of appointment so derived shall omit or fail to exercise the same within the time provided therefor, in whole or in part, a transfer taxable under the provisions of this act shall be deemed to take place to the extent of such omission or failure, in the same manner as though the persons, trustees or corporations thereby becoming entitled to the possession or enjoyment of the property to which such power related had succeeded thereto by a will of the donee of the power failing to exercise such power, taking effect at the time of such omission or failure."

It will be our aim to present the law on the subject of powers of appointment as it has developed in the eastern states and endeavor to see what this California statute as to powers of appointment ineans.

1 N. Y. Laws of 1897, Ch. $284, \S 220$, subdiv. 5 .

2 Matter of Lansing (1905) 182 N. Y. 238, 74 N. E. 882.

3 N. Y. Laws of $1911, \mathrm{Ch} .732, \S 220$.

4 Cal. Stats. 1917, Ch. 589, § 2, subdiv. 6. 
Under inheritance tax statutes that contain no provisions expressly taxing the exercise of powers of appointment the courts hold, with few exceptions, ${ }^{5}$ that the conveyance of property by the exercise of a.power of appointment relates back to the instrument creating the power of appointment and that if such instrument was executed prior to the passage of any inheritance tax statute such conveyance was not taxable, whether the power of appointment was exercised ${ }^{6}$ or not. ${ }^{7}$ These decisions are based on the principle well stated by Chancellor Kent as follows:

"An estate created by the execution of a power takes effect in the same manner as if it had been created by the deed which raised the power. The party who takes under the execution of a power takes under the authority and under the grantor of the power, whether it applies to real or personal property, in like manner as if the power and the instrument creating the power had been incorporated in one instrument."

Or, as is stated by the New York Court of Appeals in Matter of Harbeck :

"For those who take under a power of appointment take as if their naines were in the grant of the power."

In order to subject such conveyances to the taxing power, many states have adopted statutes similar to the California statute cited above, taxing transfers by the exercise of powers of appointment.

There are two constitutional questions that may arise under a statute like that adopted in California in 1917: First, has the legislature the power to tax a transfer of property passing under an exercise of a power of appointment, where the power was

${ }^{5}$ Fisher v. State (1907) $106 \mathrm{Md}$. 104, 66 Atl. 661; where a tax was imposed and the estate valued as of the date of the appointor's death instead of as of the date of the donor's deatly; Matter of Brooks (Surrogate's Ct.; 1894 ) 32 N. Y. Supp. 176; decided before Matter of Langdon (1897) 153 N. Y. 9,46 N. E. 1034 , contra.

. Commonwealth v. Duffield (1849) $12 \mathrm{~Pa}$. 277; Emmons y. Shaw (1898) 171 Mass. 410, 50 N. E. 1033; Matter of Harbeck (1899) 161 N. Y. 211, 55 N. E. 850; Attorney General v. Parker (1898) 31 Nova Scotia 202; State v. United States Trust Co. (1917) 99 Kan. 841, 163 Pac. 156; decided under a statute providing that "this act shall not apply to estates of persons deceased prior to the taking effect hereof" (Kan. Laws of 1915, Ch. 357, \$ 23). See Commonwealth v. Sharpless (1884) 2 Chester Co. Rep. 246;' Lisle's Estate (1903) $22 \mathrm{~Pa}$. Super. Ct. 262; and Commonwealth v. Williams (1850) $13 \mathrm{~Pa}$. 29; where collateral inheritance taxes were held not due because appointors exercised powers of appointment in favor of lineal descendants of the donors of the powers, although the appointees were collateral heirs of the appointors. See Hoyt v. Hancock (1903) 65 N. J. Eq. 688, 55 Atl. 1004; where an appointee was taxed as of the date of the creation of the power and not as of the date of the exercise of the power, at which time the act in force at the former date had been repealed.

7 Matter of Langdon (1897) 153 N. Y. 9, 46 N. E. 1034.

84 Kent's Commentaries, 338.

9 (1899) 161 N. Y. 211,55 N. E. 850. 
granted by an instrument executed before the passage of the act, and where the transfer of the property was the same under the power as it would have been under the instrument creating the power, had the power not been exercised? Second, has the legislature the power to tax the transfer of property under an instrument executed before the passage of the act when the instrument contained a power of appointment, which power of appointment was not exercised?

With regard to taxing a transfer of property passing by an instrument containing a power of appointment, which power of appointment was exercised so as to pass the property in the same manner as the instrument creating the power of appointment, in other words as though the power had not been exercised, the courts of New York have from the beginning held that such transfer could not be taxed as though made under the power of appointment if the appointee elected to take under the original instrument instead of under the power of appointment. ${ }^{10}$ It has even been held that an election is unnecessary and immaterial where the election would avoid a tax.11 If the instrument was executed and delivered prior to the inheritance tax statute it is unconstitutional to attempt to tax the transfer as though it were made as of the date of the exercise of the power of appointment. The leading case on this point is Matter of Lansing. ${ }^{12}$ In this case a will gave a power of appointment to the daughter of the testator in 1869 before there was any inheritance tax act in the state of New York. The will provided that the property should go to his daughter for life and the remainder to her heirs at law subject to the power of appointment in her. In 1904 the daughter devised the property to her daughter, who was her only heir. It was attempted to tax this under the New York Inheritance Tax

${ }^{10}$ Matter of Lansing (1905) 182 N. Y. 238, 74 N. E. 882; Matter of Backhouse (1906) 110 App. Div. 737; $96 \dot{N}$. Y. Supp. 466, affirmed in 185 N. Y. 544, 77 N. E. 1181; Matter of Spencer (1907) 119 App. Div. 883, 107 N. Y. Supp. 543, affirmed in 190 N. Y. 517,83 N. E. 1132; Matter of Haggerty (1908) 128 App. Div. 479, 112 N. Y. Supp. 1017, affirmed in 194 N. Y. 550, 87 N. E. 1120; Matter of Chapman (1908) 61 Misc. 593, 115 N. Y. Supp. 981, affirmed in 199 N. Y. 562, 93 N. E. 1118; Matter of Lewis (1908) 129 App. Div. 905, 113 N. Y. Supp. 1136, affirmed in 194 N. Y. 550, 88 N. E. 1124; Matter of Haight (1912) 152 App. Div. 228, 136 N. Y. Supp. 557; Matter of Hoffman (1914) 161 App. Div. 836, 146 N. Y. Supp. 898, affirmed in 212 N. Y. 604, 106 N. E. 1034; Matter of Wendel (1917) 181 App. Div. 126, 168 N. Y. Supp. 297.

11 Matter of Channcey (1918) 102 Misc. 378, 168 N. Y. Supp. 1019, affirmed in 175 N. Y. Supp. 897; Matter of Mitchell, N. Y. L. J. Nov. 22, 1913. 12 (1905) 182 N. Y. 238, 74 N. E. 882. 
Act of 1897. The New York Court of Appeals held that this could not constitutionally be done, saying as follows:

"Where there is no transfer there is no tax and a transfer made before the passage of the act relating to taxable transfers is not affected by it, because as we held in the Pell case such an act imposes no direct tax and is unconstitutional, since it diminishes the value of vested estates, impairs the obligation of contracts and takes private property for public use without compensation. ....

"Even if her interest was contingent, nevertheless, as was said .by Judge Cullen in a late case, 'the interests of the devisee accrued on the death of the testator and at that instant, and were immune from legislative attack, whether contingent or vested.' (Matter of Vanderbilt, 172 N. Y. 69, 73, citing Brevoort v. Grace, 53 N. Y. 245.)

"It is not at all necessary to determine whether the remainder which Mrs. McVickar took under her grandfather's will was vested or contingent. If we assume that the remainder was contingent, nevertheless it was acquired by Mrs. McVickar under her grandfather's will at the instant of his death. It then became a property right in her which was just as sacred and just as immune from legislative attack as any other property right. (Brevoort v. Grace, 53 N. Y. 245.)"

The principle established by this case has been followed in many New York cases. ${ }^{13}$

The Supreme Judicial Court of Massachusetts has considered the constitutionality of taxing a transfer of property under a trust deed taking effect prior to the passage of the inheritance tax act, containing a power of appointment in a person who died, without exercising the power of appointment, after the passage of the inheritance tax act. The case of Minot v. Stevens ${ }^{14}$ held that this could constitutionally be done, saying as follows:

"It is but a short step further to apply the second part of the statute, which refers to coming into succession through the conduct of the donee in refusing or omitting to make an appointment that might carry the succession elsewhere. While he has the power of appointment, he is in control of the succession. He may allow it to go to the persons named in the will or deed, or he may transmit it elsewhere. By exercising the power he may give his own creditors the benefit of it after his death. When property is held subject to such possibilities of disposition, is it usurpation or an unlawful interference with vested rights for the legislature to say that the succession in possession and enjoyment is not 
yet determined, that it belongs to no one until it is determined, that the determination of it depends upon the will and conduct of the donee of the power, and that when it is determined by his conduct, either by action or by refraining from action, it shall be subject to a tax? We think it is in the power of the legislature to say in reference to succession in possession after the death of the persons whose decease is awaited, that property so held is not vested in anybody, and that when it vests in possession, through a proper disposition of it which is dependent upon the will and conduct of the donee, a succession tax shall be imposed. We think that Chanler v. Kelsey, ubi supra, looks in this direction, although it does not discuss this particular subject. The decision in Moffitt v. Kelly, 218 U. S. 400, published since the argument in the present case, is almost, if not quite, decisive of the question.

"The decision to the contrary in Re Lansing, $182 \mathrm{~N}$. Y. 238,74 N. E. 882, was by four of the judges, two others dissenting in a well-reasoned opinion. So the decision in the Matter of Chapman, 133 App. Div. (N. Y.) 337, 117 Supp. 679, which was afterwards affirmed by the Court of Appeals in 196 N. Y. 561, without an opinion, was by three judges, while two others joined in a dissenting opinion."

The Lansing case $\mathrm{e}^{15}$ held that the exercise of the power of appointment so that the persons taking as appointees would have taken under the original instrument if the power of appointment had not been exercised, is in law equivalent to a failure to exercise the power of appointment. The court said as to this point :

"The attempt to execute the power was not effective, because it did nothing. The exercise of a power which leaves everything as it was before, is a mere form, with no substance."

The long line of New York cases ${ }^{16}$ which approved the Lansing case can fairly be said to be contra to the Massachusetts decision, which held that failure to exercise a power of appointment is equivalent to the exercise of the power and that the property shall be deemed to have passed at the death of the person holding the power of appointment. The New York rule has been applied to powers of appointment contained in instruments inter vivos, ${ }^{17}$ as well as to those contained in testamentary instruments, and to appointment by deed ${ }^{18}$ as well as by will.

15 Supra, n. 12.

16 Supra, n. 10.

17 Matter of Haight (1912) 152 App. Div. 228, 136 N. Y. Supp. 557.

18 Matter of Wendel (1917) 181 App. Div. 126, 168 N. Y. Supp. 297. 
It will be interesting to analyze the reasoning of the Supreme Judicial Court of Massachusetts. The theory of that court seems to be that as long as the power of appointment is not exercised the transfer of the property is suspended and cannot be said to be effective until the death of the person in whom the power of appointment is vested. The court says in one part of its opinion that the succession in possession and enjoyment "belongs to no one until it is determined, that the determination of it depends upon the will and conduct of the donee of the power." The court approves the dissenting opinion in Matter of Lansing, referring to it as, "a well-reasoned opinion." The point of difference between the majority and the minority of the court in Matter of Lansing is well stated in the majority opinion, where the court says :

"The difference between my brother Haight and myself is that he maintains that Mrs. McVickar's rights accrued on the death of her mother, while I insist they accrued on the death of her grandfather" (Mrs. McVicker was the appointee under the power);

or, as it is put by the minority:

"As we have seen, Mrs. McVickar did not become vested with the estate until the death of her mother. Upon the happening of that event she became vested and entitled to the immediate possession of the property. Her right of succession then accrued and the transfer to her dates from that event."

And, further on, the minority of the court said:

"It is now proposed that this court should hold that the immunity from the transfer tax should be extended to contingent remainders under the authority of Matter of Vanderbilt, 172 N. Y. 69, 73."

It is apparent from the language of the Massachusetts case and from the opinion of the minority in the Matter of Lansing, supra, to which the Massachusetts court refers with approval, that the Massachusetts court, and the minority of the New York court, fell into error through overlooking the principle that instruments creating estates in property, whether vested or contingent, from the point of view of constitutional law, created vested rights. In other words, irrespective of whether the interests created were contingent or vested estates, the interests were vested rights, since they owed their existence to the instruments creating them and could not be enlarged or diminished by any authority, except that contingent interests might never become effective because of the occurrence or non-occurrence of some 
event expressly mentioned in the instrument creating them. Contingent interests could be defeated only by virtue of the terms of the instrument creating them and by no other means or authority. The theory relied upon by the Massachusetts court and the minority of the New York court, in Matter of Lansing, supra, ignores two fundamental rules of law.

The first is that an instrument transferring property interests and contaiming a power of appointment or of revocation creates vested rights when it becomes effective. It is true that these vested rights may be contingent subject to defeasance by the exercise of the power of appointment or of revocation in such a way as to prevent the passing of the property in the manner contemplated. This, however, is in effect a transfer subject to a condition subsequent, and the transfer is fully completed when the instrument making it becomes effective. An interesting case in California to this effect is the case of Gray v. Union Trust Company. ${ }^{19}$ Here the grantor conveyed property to a trustee in trust to pay the income to herself for her life and the remainder to her heir at law, subject to a power of appointment by will in herself. After the execution and delivery of this deed the grantor brought an action to terminate the trust and it was held that the heirs at law had vested interests under the deed which could not be defeated, even though their estates were only contingent. As to this point the court said:

"There is in this trust a power of appointment or nomination reserved to the trustor. It can be exercised in but one way, and that is by her will. But such power of appointment does not prevent the vesting of the future estate in remainder. (Civ. Code, Sec. 781.) Everything, then, which the law contemplates shall exist for the creation of equitable remainders or remainders in trust is found in this trust. Whether they be regarded as vested or contingent is immaterial, for in either case the estate and interest are alienable. (Davis $v$. Willson, $115 \mathrm{Ky} .639,74 \mathrm{~S}$. W. 696; McDonald v. Bayard Sav. Bank, 123 Iowa, 413, 98 N. W. 1025; Sikemeier v. Galvin, 124 Mo. 367, 27 S. W. 551.) But in truth these remainders are to be regarded as vested remainders, subject to divestiture only upon the exercise of the power of nomination by will reserved to the trustor."

In the case of Tennant v. Tennant Memorial Home, ${ }^{20}$ the grantor granted certain property and reserved to herself the possession, use and enjoyment of the rents, issues and profits of 
the real estate granted for her life and she also reserved to herself the power to revoke the deed and to sell and convey the property during her life. The Supreme Court of California held that this was a valid deed vesting the transferred estate in the grantee. With regard to these reservations, the court said as follows:

"Notwithstanding these reservations and this privilege of enjoyment, she did then, in fact and in law, convey to the grantee the future estate which, at her death, became an estate in possession to said grantee. The deed was not the same, in effect, as a will. It passed a present interest in the remainder, upon the contingency that the grantor should not, during her life, convey to another, or revoke the deed. The will would have had no such effect. The contingencies did not happen, hence the estate is now absolute."

Furthermore, it has almost universally been held that, where a deed transferring estates and creating future interests was executed before the passage of an inheritance tax act, the coming into possession and enjoyment of the future interests subsequent to the passage of the act could not be taxed thereunder, even though the future interests might be contingent. The leading case on this point is the case of In re Pell, ${ }^{21}$ which is quoted with approval in the California case of Hunt $v$. Wicht, ${ }^{22}$ where it was said:

"In New York the matter is thoroughly settled by several decisions. In the Matter of Pell, $171 \mathrm{~N}$. Y. 48, 55, 80 Am. St. Rep. 791, 57 L. R. A. 540, 63 N. E. 789, it is said that such a transfer tax being one not imposed on property, but upon the right to succession, it 'follows that where there was a complete vesting of a residuary estate before the enactment of the transfer tax statute, it cannot be reached by that form of taxation.' And also, 'If these estates in remainder were vested prior to the enactment of the transfer tax act there could be in no legal sense a transfer of the property at the time of possession and enjoyment. This being so, to impose a tax based on the succession would be to diminish the value of these vested estates, to impair the obligation of a contract and take private property for public use without compensation." ".

This Pell case has been followed in many other jurisdictions, including the states of Iowa, ${ }^{23}$ Maryland, ${ }^{24}$ Michigan, ${ }^{25}$ Minnesota, ${ }^{26}$

21 (1902) 171 N. Y. 48, 63 N. E. 789.

22 (1917) 174 Cal. 205, 162 Pac. 639.

23 Lacey v. State Treasurer (1911) 152 Ia. 477, 132 N. W. 843.

24 State v. Safe D'eposit \& Trust Co. (1918) 132 Md. 251, 103 Atl. 435.

25 Miller v. McLaughlin (1905) 141 Mich. 425, 104 N. W. 777.

26 State v. Probate Court (1907) 102 Minn. 268, 113 N. W. 888. 
Ohio, ${ }^{27}$ New Hampshire, ${ }^{28}$ Virginia ${ }^{29}$ and Kentucky ${ }^{30}$ and Hunt v. Wicht has been approved by the California Supreme Court several times. ${ }^{31}$ From these authorities it must follow that the Supreme Court of California is now bound by the rule that, even though instruments transferring property by deed or devise contain powers of appointment, or of revocation, or create contingent interests, if the instruments became effective prior to any inheritance tax act, no $\operatorname{tax}$ can be levied when death follows and the contingent interests come into possession and enjoyment.

We are not to be understood as contending that under no circumstances can any American jurisdiction tax retroactively a completed transfer made in contemplation of death, or intended to take effect at or after death. Under such circumstances the legislators must keep in mind that they are levying a direct tax, and that they must comply with all the constitutional provisions governing such taxes. Many an inheritance tax act now in force, if considered as levying a direct tax, would violate the constitution of the jurisdiction in which it was enacted.

In the famous Pell case the Appellate Division of New York ${ }^{32}$ sustained the act there involved as levying a direct tax, and the New York Court of Appeals $^{33}$ agreed with the appellate division that the legislature had the power to levy such a direct tax. The court of appeals, however, refused to consider the inheritance tax act in question as levying a direct tax, in view of its obvious purpose to levy a tax on successions and transfers, and held it invalid. The court said that even considering the act as levying a direct property tax, it was unconstitutional in two respects: first, because it subjected certain designated persons, defined by the character of their ownership, to the payment of the tax, and secondly, because of its maintaining different rates of taxation, thus discriminating between different owners.

In Hunt v. Wicht, supra, ${ }^{34}$ the California Supreme Court held the retroactive provision of the inheritance tax act unconstitutional without even considering it as imposing a direct tax on property.

27 Executors of Eury v. State (1905) 72 Ohio St. 448, 74 N. E. 650.

${ }^{28}$ Carter v. Whitcomb (1908) 74 N. H. 482,69 Atl. 779.

29 Commonwealth v. Wellford (1913) 114 Va. 372, 76 S. E. 917. W. 411

30 Commonwealth v. McCauley's Executor (1915) 166 Ky. 450, $179 \mathrm{~S}$.

31 Estate of Felton (1917) 176 Cal. 663, 169 Pac. 392; Estate of Guernsey (1918) 177 Cal. 211, 170 Pac. 402; Nickel v. State (1918) 56 Cal. Dec. 359, 175 Pac. 641.

32 Matter of Pell (1901) 60 App. Div. 286, 70 N. Y. Supp. 196.

33 Supra, n. 21.

3 Supra, n. 22. 
It did this undoubtedly because there was no suggestion in the act that it was intended to be a direct tax. However, even as a direct tax provision it would violate the provisions of the California constitution requiring all property to be taxed in proportion to its value, ${ }^{35}$ requiring all laws of a general nature to have a uniform operation, ${ }^{36}$ and prohibiting special legislation, ${ }^{37}$ because of its different exemptions and varying rates of taxation.

In discussing the Federal estate tax act hereafter we desire to have it borne in mind that we do not deny that Congress has the power to tax transfers completed prior to the passage of the estate tax act, but that we contend that Congress in doing so would be levying a direct tax which would be unconstitutional unless apportioned according to census or enumeration as required by Article I, section 9, of the United States Constitution..$^{38}$ The passage of property under instruments containing powers of appointment never exercised is analogous to property passing under instruments containing powers of revocation never exercised, as well as being analogous to instruments creating interests subject to defeasance, which contingent interests are not defeated, but go into effect as planned.

The Supreme Judicial Court of Massachusetts cited two cases from the United States Supreme Court, Chanler v. Kelsey, ${ }^{39}$ and Moffitt v. Kelly, ${ }^{40}$ as tending to support its decision. Examination of the case of Chanler v. Kelsey shows it to be clearly distinguishable from the Massachusetts case and in no way to strengthen that decision. The facts in that case were that a Mrs. Delano was given deeds by her father conveying property to her for life with remainder to her issue in fee or, in default of issue, to her heirs in fee and giving her power in her discretion to appoint the remainder amongst her said issue or heirs in such manner and proportions as she might appoint by instruments in their nature testamentary. The donee of the power exercised the power in favor of one nephew, cutting off other children of her brother. The Court of Appeals of New York, in the Matter of Dielano, ${ }^{41}$ taxed this exercise of the power of appointment on the ground that the beneficiary under his grandfather's will creating the power

${ }^{35}$ Const. of Cal., Art. XIII, $\$ 1$.

36 Const. of Cal., Art. I, $\S 11$.

37 Const. of Cal., Art. IV, $\$ 25$.

38 Pollock v. Farmers Loan \& T. Co. (1895) 158 U. S. 601, 39 L. Ed. 1108,

15 Sup. Ct. Rep. 912; Eisner v. Macomber (1920) 64 L. Ed. Adv. Ops. 248.

${ }_{39}$ (1907) 205 U. S. 466, 51 L. Ed. 882, 27 Sup. Ct. Rep. 550.

40 (1910) 218 U. S. 400, 54 L. Ed. 1086, 31 Sup. Ct. Rep. 79.

41 (1903) 176 N. Y. 486,68 N. E. 871. 
of appointment would have received only one-fourth of the estate if the power of appointment had not been exercised, whereas, by reason of his aunt's exercise of the power of appointment, he got the whole of the estate in remainder. The New York Court of Appeals made it clear that if the power of appointment had not been exercised it would have held the transfer to have taken place under the grandfather's will and, therefore, not to have been taxable. The language of the court on this point is as follows:

"If the power had not been exercised, the question would have resembled that presented by the Pell case, relied upon below, where we held that a statute was unconstitutional which imposed a tax upon such remainders, already vested and non-defeasible, as should result in an absolute title after the passage of the act (Matter of Pell, 171 N. Y. 48). In that case the transfer was completed without the aid of a will and the effect was the same as a deed inter vivos. There was no foundation for a succession tax, which is a charge upon the right to make a will, or on the right to inherit without a will."

This case was sent back to the Surrogate's court, which taxed the exercise of the power in accordance with the opinion on appeal, and this order was affirmed by the New York Court of Appeals. ${ }^{42}$ From this judgment an appeal was taken to the United States Supreme Court, which sustained the New York Court of Appeals. The United States Supreme Court made it clear that it approved of the tax only because the New York Court of Appeals had specifically found that the property passed by the exercise of the power of appointment and not under the will creating the power of appointment. The United States Supreme Court said on this point as follows:

"As in Orr v. Gilman, supra, we must accept this decision of the New York Court of Appeals holding that it is the exercise of the power which is the essential thing to transfer the estates upon which the tax is imposed. That power was exercised under the will of Laura Delano, a right which was conferred upon her under the laws of the State of New York and for the exercise of which the statute was competent to impose the tax in the exercise of the sovereign power of the legislature over the right to make a disposition of the property by will."13

Had Mrs. Delano, by the exercise of her power of appointment, transferred the property to the same persons and in the same

42 Matter of Delano (1906) 183 N. Y. 543, 76 N. E. 1093.

43 Supra, n. 39. 
proportions as her father did by the deeds, the Massachusetts court might have relied on this case as an authority to support its decision, but, since Mrs. Delano, by the exercise of her power of appointment, disposed of the property differently than her father did, which was the sole ground of the decision of the New York Court of Appeals, this case must be an authority against the decision of the Massachusetts Supreme Judicial Court rather than in support of it.

The case of Moffitt v. Kelly, ${ }^{44}$ the other case cited by the Massachusetts court, affirmed the case of Estate of Moffitt, ${ }^{45}$ which held that the State of California had a right to tax the right of a surviving wife in community property, even though the marriage contract had been entered into prior to the enactment of any inheritance tax act. Aside from the fact that no question relating to a power of appointment is present in the case, the case can be no authority in support of the decision of the Supreme Judicial Court of Massachusetts, since the Supreme Court of California specifically held that the wife had no vested interest in the community property prior to the dissolution of the community. The Supreme Court of California in one part of its opinion said:

"Thus the legislature is presumed to have enacted it [the inheritance tax act] with full knowledge that this court in Bank, not once but repeatedly, had declared that the wife did not take her share of the community property as his heir."

And elsewhere said:

"And again Mr. Justice Thornton, speaking for the court in Greiner v. Greiner, $58 \mathrm{Cal}$. 111, says, 'The interest of the wife during the same period (coverture) was a mere expectancy like the interest which an heir may possess in the property of his ancestor."

This case was appealed to the United States Supreme Court and two grounds were relied on: first, that there was a violation of the contract clause of the United States Constitution, and, secondly, that there was a violation of the equal protection of the laws clause of the United States Constitution.

The decision of the California court was affirmed, and as to the first ground of appeal the United States Supreme Court in substance held that the legislature had power to tax "the vesting in complete possession and enjoyment by wives of their shares of 
community property consequent upon the death of their husbands and the resultant cessation of their power to control the same and enjoy the fruits thereof." 46 As to the second ground, the United States Supreme Court said "the nature of the character of the right of the wife in the community for the purpose of taxation was peculiarly a local question which we have no power to review." It must be clear, then, that there is nothing in the case of Moffitt v. Kelly in any way supporting the decision of the Massachusetts court. The first ground relied on by the United States Supreme Court is in no way applicable to the Massachusetts case, since the United States Supreme Court was dealing with the vesting of a right at death which had been held by the state court to be a "mere expectancy" prior to death. In the Massachusetts case the rights of the party appealing, as constitutional rights, were vested when the instrument creating the power of appoimtment was executed and delivered, irrespective of whether the estate he obtained was vested or contingent according to the rules of real property. The decision on the second point is rested on the ground that only a local question was involved, which could not be reviewed by the United States Supreme Court, so no support can be gained from the second ground of the decision.

The Massachusetts case of Minot v. Stevens ${ }^{47}$ is followed in the case of Burnham v. Stevens. ${ }^{48}$ The only additional authorities cited by the Massachusetts court in this case are Attorney General v. Stone ${ }^{49}$ and Keeney v. Comptroller. ${ }^{50}$ The former case is not in point, as a consideration of its facts shows. In that case a remainder was taxed when the remainder man came into possession instead of when the will creating the remainder became effective. At the time that the will creating the remainder became effective, there was an inheritance tax statute in effect, requiring the tax on the remainder interest to be paid within two years after the qualification of the executor. The tax was not paid and before the remainder man came into possession and the tax was collected, the statute was changed in several respects, but it made no substantial change in the duties of the remainder man. Since no tax had ever been collected on the conveyance by the instrument which took effect after the passage of the inheritance tax

46 Supra, n. 40.

47 Supra, n. 14.

18 (1912) 212 Mass. 165,98 N. E. 603.

10 (1911) 209 Mass. 186, 95 N. E. 395.

60 (1912) 222 U. S. 525, 56 L. Ed. 299, 32 Sup. Ct. Rep. 105. 
act, there could be no objection to taxing the remainder when it came into possession.

In the latter case a transfer by deed, intended to take effect upon the death of the grantor, executed in 1903, was subjected to a tax under the statute of 1896 . From the facts in the case it is evident that there is nothing in it that could support the rule laid down by the Massachusetts court as to powers of appointment.

The Supreme Court of Wisconsin, in Montague v. State, ${ }^{51}$ has followed the rule laid down by the Massachusetts court on the same reasoning and cites Burnham v. Stevens. ${ }^{52}$

The New York courts have applied the New York rule logically, and have held that where a power of appointment was exercised so as to transfer part of the property conveyed by the instrument creating the power, in a different manner from the instrument creating the power, only the part of the property so transferred was subject to tax, whereas the part of the property not transferred by the exercise of the power of appointment, or transferred in the same way by the power of appointment as by the instrument creating the power, was held not taxable. ${ }^{53}$

The Federal estate tax act taxes only the exercise of general powers of appointment, ${ }^{54}$ and the Internal Revenue Department has ruled that the property passing by an exercise of a power is part of the appointor's gross estate, even though the persons to whom the appointment was made would have taken the property had the power not been exercised. ${ }^{55}$

The Federal estate tax act taxes the exercise of powers of appointment whether the powers were exercised by will, or by deed executed in contemplation of death or intended to take effect at or after death. In the case of such deeds the act is silent as to whether such a deed, exercising a power, must have been executed after the passage of the act to make the exercise of the power taxable, but the Internal Revenue Department has ruled that the date of the exercise of the power by deed is immaterial. ${ }^{56}$ In view of the authorities discussed herein, these rulings of the Internal Revenue Department would seem to be unjustified.

51 (1916) 163 Wis. 58,157 N. W. 508.

52 Supra, n. 48.

53 Matter of Slosson (1915) 216 N. Y. 79, 110 N. E. 166; Matter of Ripley (1907) 122 App. Div. 419, $106 \mathrm{~N}$. Y. Supp. 844, affirmed in $192 \mathrm{~N}$. Y. 536, 84 N. E. 1120. 1919.

$54 \S 402$, subdiv. (e) of the Revenue Act of 1918, approved February 24,

55 Art. 30, Regulations 37 (revised 1919), of the Treasury Department, relating tơ estate tax.

56 Supra, n. 55. 
Summarizing our conclusions, it is our belief that future interests created by deeds or wills, whether consisting of vested or contingent estates, which are subject to the exercise of powers of appointment, constitute rights which are vested as of the date when these instruments become effective. Such interests are taxable only under the law in force at the time of their creation. If the powers of appointment are exercised so as to change such future interests, such exercise can be subjected to tax under appropriate statutes, without constitutional objection.

San Francisco, California.

Delger Trowbridge. 